\title{
Pragmatics Analysis:Arabic Directive Imperative Speech Acts Used in Alquran
}

\author{
Nurtaqwa Amin ${ }^{1}$, H.Najmuddin H. Abdul Safa ${ }^{2}$, H. Muhammad Darwis ${ }^{3}$, Tadjuddin Maknun ${ }^{4}$ \\ ${ }^{1}$ Post Graduate Student, Linguistic Departement, Hasanuddin University, Makassar City, Indonesia \\ ${ }^{2}$ Professor, Arabic Departement, Hasanuddin University, Makassar city, Indonesia \\ ${ }^{3}$ Professor, Linguistic Departement, Hasanuddin University, Makassar City, Indonesia \\ ${ }^{4}$ Professor, Linguistic Departement, Hasanuddin University, Makassar City, Indonesia
}

\begin{abstract}
This study concerns with directive imperative speech acts in Al-Quran. It aims to revel types of directive imperative speech acts used in Alquran, as well as the functions of the directive speech acts.The study applies the pragmatics approach and a contextual method. Data are analyzed using an informal method.Results of the study show that there are four types of directive imperative speech acts used in Alquran, namely:(1) direct speech acts that are formed in imperative sentences, (2) indirect speech acts formed in declarative sentences, (3) literal speech acts, and (4) non-literal speech acts. The directive speech acts in Alquran function to command, to prohibit, to advise, to call upon, as well as to show hopes, to remind, and to express prayers (supplications).
\end{abstract}

Keywords: Directive Speech Acts, Imperative, Arabicin Al-Quran, Pragmatics

\section{Introduction}

According to Wijana (2010), one of speech acts that is investigated in a study of pragmaticsis directive speech act, which is expressed by a speaker with the intention of making the interlocutor to do something. This type of speech act can be used for different purposes, which are affected by either linguistics or non-linguistics factors. This is because the usages of directive form themselves have been diverse, as they can be used as a command, a statement, or a question. In addition, the functions of directive speech acts are also varied - to command, to prohibit, to beg, to advise, etc.

In light of this, it is important to conduct a study on the pragmatics of Arabic language, particularly the Arabic fusha used in Alquran, given the wealth of meaning embedded in it. An incorrect meaning interpretation of Alquranmay lead to incorrect implementations. For this reason, the current study attempts to look into the directive imperative speech acts of Arabic language used in Alquran.

Based on the rationales above, the study was set out to:

a) Reveal types of directive imperative speech acts of Arabic language that are used in Alquran.

b) Reveal the functions of directive speech acts of Arabic language that are used in Alquran.

\section{Theoretical Review}

Several definitions of pragmatics have been proposed by experts. Levinson (1983), for example, states that pragmatics is a study of the relationship between language andcontext, which is fundamental to understanding a language. According to Yule (2006), pragmaticsis concerned with meaning that is expressed by a speaker and how it is interpreted by its listener.As such, a study of pragmaticsplaces more emphasis on the relationship between meaning of speech expressed by a speaker rather than on the lexical meaning of words or phrases used in the speech.

One area of investigation in a study of pragmatics is speech act. In a theory of speech act, Searle (in Wijana, 1996) states that pragmatically speaking there are at least three acts that can be realized by a speaker when using a language, they are: an act of speaking (a locutionary act), an act of doing something (an illocutionary act), and an act of influencing the interlocutor (a perlocutionary act).

According to the theory of speech acts, an illocutionary act is central to an analysis of speech act. Searle (1979) offers five classifications of speech acts, includingassertive, directive, expressive, commisive, and declarative. Anassertive speech act is used to express the extent to which a speakeres utterance is believed to be right or wrong, for example a statement of fact, affirmation, conclusion, anddescription. A directive speech act is meant to make an interlocutor does what a speaker says. An expresive speech act is used to express what a speaker feels. A commisive speech act is expressed by a speaker to relate himself to future actions. A declarative speech act produces an utterance that changes something in a relatively short time.

The current study focuses on directive speech act only. This type of speech act can have a variety of functions and meanings. This study follows the classification of directive speech acts based on intention and meaning as proposed by Searle (1979), Levinson (1983), Yule (2006), Wijana (2010), and Rahardi (2010). These include commanding, ordering, asking for, advising, praying, inviting, permitting, defending, begging, and recommending.

It is important to refer to Wijana (1996) who states that a speech act can be direct or indirect, and it can also be literal or non-literal A direct speech act is one whose function is in accord with its form, for example an interrogative sentence is meant to ask a question, a declarative sentence to declare,

Volume 6 Issue 1, January 2017 


\section{International Journal of Science and Research (IJSR) \\ ISSN (Online): 2319-7064}

Index Copernicus Value (2015): 78.96 | Impact Factor (2015): 6.391

and an imperative to command or to prohibit. In contrast, indirect speech act aims at achieving something that is not necessarily in accord with its form. For instance, rather than to ask, an interrogative sentence is used to order. A declarative sentence may be used to offer,rather than to declare, something, etc. When a literal speech act is used, the intention is the same as meaning of words used, whereas in a non-literal one the intention is different from or even contradictory to the meaning of words being used.

\section{Research Method}

This study goes through three stages: data collection, data analysis, and presentation of analysis results. In the first stage, data were collected from Alquran by carefully reading the source of data.A notetaking technique is employed here. Then, the researcher collected data of sentences which contain directive speech acts. This was done by closely looking into sentences in Alquran verses and the context which became the background for the revelation of the verses (asbab nuzul).

In the next stage, collected data were analyzed by using a contextual analysis method, which is a way of analyzing data that is based on context, by considering and relating identities of existing contexts (Rahardi, 2005). In this case, an interpretation of a sentence is always preceded by a presentation of its context. The last stage is data presentation by using an informal metode (Sudaryanto, 1993), that is, results of the study are presented descriptively using words without any symbols.

\section{Discussion}

Based on the analysis, it is revealed that there are many types and functions of directive imperative speech acts used in Alquran. What follows is a description of these types and functions.

\section{1) Types of Arabic Imperative Speech Acts used in Al- Quran}

Data obtained from Alquran show that there are many instances of imperative speech acts used in Alquran, and they can be grouped into four types, namely direct directive speech act, indirect directive speech act, literal directive speech act, and non-literal directive speech act. The following table presents data of Arabic directive speech acts used in Alquran that have classified according to types.

\section{a) Direct Speech Acts}

In Alquran, several verses can be categorized into direct speech acts, such as the followings

- Chapter al-Syuara' (26), verse 214-215

Translation: "214:And warn your nearest relations;215. And be kind to him who follows you of the believers."

- Chapter al-Maa'idah (5), verse 105

Translation: "105. O you who believe! Take care of your souls; he who errs cannot hurt you when you are on the right way; to Allah is your return, of all (of you), so He will inform you of what you did."

The first instance/verse above uses an imperative sentence, as can be seen in the use of imperative verb (fi'il amar), namely /andzir/ which means warn themand /ahfidh/"elower it down. This imperative sentence is used in accordance to its function, i.e., to give a command, so it can be considered as a direct speech act. The second verse is another example of imperative sentence,signified by the use of isim-fi'ilas a substitute for fi'il amar. This imperative sentence is also used to conform with its function, that is, to give a command, so it can be categorized into a direct speech act. The use of this form is related to the context of event, situation, message, and participant (intended to believers).Thus, it emphasizes on the quality of the command, which points out the need to really carefully take care of oneself, as indicated by the next sentence that those ashtray people will never be able to afflict harmfulness on you once you have been guided, and only to Allah you all will return.

\section{b) Indirect Speech Acts}

In Alquran, some verses are indirect speech acts, such as

- Chapter Thaaha (20), verse 44

Translation: "44. Then speak to him a gentle word haply he may mind or fear".

- Chapter al-Anbiya' (21), verse 83

Translation: "83. And Ayub, when he cried to his Lord, (saying): "(O my Lord!), Harm has afflicted me, and Thou art the most merciful or the merciful."

The verse in example (1) is an imperative sentence as shown by the use of an imperative verbs (fi'il amar),/faquulaa/ ,say it $^{\text {ee }}$ (talk). This sentence is used not only to command, but also to guide into an ethic of speaking (manner in using a language).Therefore, the sentence is categorized as an indirect speech act. Example (2) is a declarative sentence that is used not only to inform a news, but also to hope for something, i.e. the mercy of Allah the Almighty to cure the illness. Thus, this sentence is another example of an indirect speech act.

\section{c) Literal Speech Acts}

The followings are some examples of literal speech acts found in Al-Quran:

\section{Chapter Maryam (19), verse33}

Translation: "33. And peace on me on the day I was born, and on the day I die, and on the day I am raised to life".

The above verse is a sentence uttered by Prophet Isa p.b.u.h, which he conveys to Allah the Almighty. It is meant to be a pray of the prophet to Allah the Almighty, in which he is begging Allah to bestow him with prosperity on the day he was born, on the day he died, and on the day he is resurrected. An imperative sentence is being used here, as can be seen in the use of isim masdar, which means ,hope for a salvation (prosperity) $)^{e c}$ In this case, the real meaning of the sentence is exactly the same as the meaning of every single word in the sentence combined. Thus, it is a literal speech act.

\section{d) Non-Literal Speech Acts}

Non-literal speech acts are also used in Al-Quran, as can be seen in the followings instances

\section{Chapter al-Baqarah (2), verse 67}

Translation:"67. And whenMoses said to his people: Surely Allah commands you that you should sacrifice a cow; they

\section{Volume 6 Issue 1, January 2017}




\section{International Journal of Science and Research (IJSR) \\ ISSN (Online): 2319-7064}

Index Copernicus Value (2015): 78.96 | Impact Factor (2015): 6.391

said: Do you ridicule us? He said: I seek the protection of Allah from being one of the ignorant".

The verse above is a short conversation between Prophet Moses pbuh and his people, in whichthe prophet asks them to slaughter a female cow. A declarative sentence is being used here to imply an order. The real meaning of the sentence is actually not only to order people to slaughter a cow. It is more than that - it aims to remove people es respect to the animal that they worship. Thus, the sentence is meant to prohibit people from worshipping cows. Given this meaning, the prophets ${ }^{\text {ee }}$ sentence is a non-literal speech act since the real meaning of the sentence goes beyond the literal meaning of every single words in the sentence.

\section{2) Functionsof Arabic Imperative Directives Speech Actsin Alquran}

Based on data obtained, the use of directive speech acts of Arabic language in Alquranserves a number of functions, including to command, to invite, to order, to prohibit, and to pray (supplication), as well as to indicate hopes, advices, and reminders. These functions can be seen in the following instances:

a) Chapter al-Baqarah (2), verse 83

Translation: "83.And when We made a covenant with the children of Israel: You shall not serve any but Allah and (you shall do) good to (your) parents, and to the near of kin and to the orphans and the needy, and you shall speak to men good words and keep up prayer and pay the poor-rate. Then you turned back except a few of you and (now too) you turn aside"

The verse above contains a directive meaning, which functions as a strict order. The order is issued in accordance to the context of the event, participants, and message (topic) related to the revelation of the verse, in which Allah the Almighty commands the Children of Israel to worship nothing but Allah,and then after that they are obliged do good deeds to parents, orphans, and poor people. The message is preceded by an order to believe in one god only. Thus, in addition to the context which indicates an obligation, the grammar of the language (usul fiqh) also implies that the order is obligatory.

b) Chapter Nooh (71), verses 10-12

Translation: "10.Then I said, Ask forgiveness of your Lord, surely He is the most forgiving. 11. He will send down upon you the cloud, pouring down abundance of rain; 12. And help you with wealth and sons, and make your gardens, and make for you rivers."

The verse above contains a directive meaning and it functions to invite as well as to advise. The meaning and function of the verse is related to the context of situation, participant, and message (topic), in which the Prophet Noah invites his people to beg the mercy of Allah the Almighy, and at the same time advises that Allah is the Most Forgiving, who can send down rains, wealth, children, and other sustenance such as gardens and rivers.

c) Chapter al-Anbiya'(21), verse 24

Translation:"24. Or, have they taken gods besides Him? Say: Bring your proof; this is the reminder of those with me and the reminder of those before me. Nay! Most of them do not know the truth, so they turn aside."

This verse has a directive meaning that functions as a reminder. The meaning and function of the sentence corresponds with the context of situation, participants, and message (topic), in which the Prophet Muhammad pbuh remind his people of how they turned away from him because they did not know the truth.

\section{d) Chapter Hud (11), verse 55-56}

Translation:"55.Besides Him, therefore scheme against me all together; then give me no respite; 56. Surely I rely on Allah, my Lord and your Lord; there is no living creature but He holds it by its forelock; surely my Lord is on the right path."

The verse above has a directive meaning which is meant to run trickery, although its real function is to prohibit. The meaning and function of the sentence is in agreement with the context of situation, participant, and content (topic), in which the Prophet Hud pbuh orders him people to do something, whereas he actually prohibits them to do so, as can be seen in the next sentence which indicates that he has fully trusted himself to Allah, his god and their god, and that Allah is the Almighty for everything.

\section{e) Chapter al-A'raf (7), verse 23}

Translation: "23. They said: Our Lord!We have been unjust to ourselves, and if Thou forgive us not, and have (not) mercy on us, we shall certainly be of the losers"

The verse above has a directive meaning and functions tobeg a mercy. This meaning and function is correlated to its context of situation, participant, and message (topic), which is an utterance expressed by the Prophet Adam pbuh and Eve to beg Allah'es mercy, followed by an admittance that if You do not forgive us and do not give us Your mercy, then we would definitely be among the losers.

\section{f) Chapter al-Anbiya'(21), verse 83}

Translation:"83. And Ayub, when he cried to his Lord, (saying): Harm has afflicted me, and Thou art the most Merciful of the merciful."

The verse above contains a directive meaning and functions as a hope. The meaning and function conform with its context of situation, participant, and message (topic), in whichProphet Ayyub pbuhprays to Allah the Almighty, hoping for Allah"s mercy and begging that he can be cured from his illness, as indicated by the next sentence "You are the God the Most Merciful among the merciful." The prophet expressed this when he was suffering from a very severe illness.

\section{Conclusions and Suggestions}

\section{Conclusion}

Based on the research results and discussion about directive speech acts of Arabic language used in Al-Quran, the following conclusions can be drawn:

a) There are four forms of directive speech acts of Arabic language used in Alquran including imperative direct 


\section{International Journal of Science and Research (IJSR) \\ ISSN (Online): 2319-7064}

Index Copernicus Value (2015): 78.96 | Impact Factor (2015): 6.391

speech acts, declarative indirect speech acts, literal speech acts, and non-literal speech acts.

b) The directive speech acts of Arabic language used in AlQuran serve several functions, including to command, to prohibit, to advise, and to invite, as well as to show hopes, to remind, and to pray(supplications).

\section{Suggestions}

A study on imperative sentences in Alquran covers a very wide area and involves massive amount of data. Since this study only focuses on the directive imperative speech acts, further research needs to be conducted. Future studies may look into other imperative forms and meaning, or they can use different approaches to investigate current topic more comprehensively. The current study is highly significant in that it contributes to the development of linguistics theory, especially as far Arabic semantic and pragmatics is concerned. Besides, the study offers a practical significance and benefit to people in their efforts of manifesting qureanic verses in their life, not only in building their relationship to Allah the Almighty (the Creator of the Universe) but also to other human beings.

\section{References}

[1] Levinson, $\quad$ Stephen. $1983 . \quad$ Pragmaticss. London.Cambridge,Massachusetts: Blacwell Publishers.

[2] Rahardi, Kunjana. 2010. Pragmatik Kesantunan Imperatif Bahasa Indonesia. Jakarta: Penerbit Erlangga.

[3] Searle, J.R. 1979. Expression and Meaning Studies in the Theory of Speech Act. Cambridge: Cambridge University Press.

[4] Sudaryanto. 1993. Metode dan Aneka Teknik Analisis Bahasa. Yogyakarta: Duta Wacana Press.

[5] Wijana, I Dewa. 1996. Dasar-dasar Pragmatik. Yogyakarta: Penerbit Andi.

[6] Wijana, I Dewa. 2010. Pengantar Semantik Bahasa Indonesia. Yogyakarta: Pustaka Pelajar.

[7] Wijana, I Dewa \& Rohmadi, Muhammad. 2012. Sosiolinguistik Kajian Teori dan Analisis. Yogyakarta: Pustaka Pelajar.

[8] Yule, George. 2006. Pragmatik. Penerjemah Indah Fajar Wahyuni. Yogyakarta: Pustaka Pelajar.

\section{Author Profile}

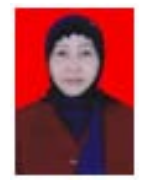

Nurtaqwa Aminis a lecturer of ArabicLanguage at Universitas Muslim Indonesia in Makassar, Indonesia. She was born in Watampone, South Sulawesi, Indonesia on May $16^{\text {th }}, 1966$. She earned her bachelor degree (Dra) in 1989from Hasanuddin University, Indonesia, and her master degree (M.Hum.) in 1999from State University of Makassar, Indonesia.Since 2011, she has been pursuing her doctorate degree on Linguistics at the Faculty of Cultural Science in Hasanuddin University, Indonesia. This paper is part of her dissertation entitled „Relationship between Linguistic Structure and Context in the Meaning of Imperative Sentences in Alquran: A Semantic-Pragmatic Analysis ${ }^{\text {ee }}$ which is supervised by Prof. Dr. H. Najmuddin H. Abd. Safa, M.A (promotor), Prof. Dr. H.Muhammad Darwis, M.S. and Prof. Dr. Tadjuddin Maknun, S.U.. (Co-promotors). 